GAP GYAN- An International Peer-Reviewed

Open Access Journal of Social Sciences

\title{
INDIAN APPROACH TOWARDS RIGHT TO LIFE WITH REFERENCE TO WATER AND SANITATION
}

\author{
MS. AMISHI D. PATEL \\ Ph.D. Research Scholar, University School of Law, Gujarat University, Ahmedabad \\ prof.amishishah@gmail.com \\ DR. BHAVESH H. BHARAD \\ Assistant Professor, \\ University School of Law, Gujarat University, Ahmedabad \\ dr.bharad@gmail.com
}

\begin{abstract}
Water is the essence of life. It is the most substantial substance of earth. Living organism - be it plants or animals require water for survival. Non-availability of water is equal to denial of right to life. It is rightly said "no water - no life". Hence, any disavowal of water would imply a denial of right to life. Closely connected to water is right to sanitation facilities. Water and sanitation are essentially about access to clean water, basic sanitation and good hygiene practices, all of which are essential to human development. People of various countries including India is facing water crisis and adequate sanitation facilities in different parts.

The right to water and sanitation facilities are not enshrined in the Indian Constitution as an explicit Fundamental Right but the Indian Judiciary, both at the state as well as at the centre, has in several judgments interpreted Article 21 of the Constitution to include a right to clean and sufficient water, a right to adequate sanitation, a right to a decent and well life, a right to live with dignity and with peace, and a right to a humane and healthy environment which would certainly imply a right to water and sanitation to all the members of the society especially human beings.

The government has schemes and policies to provide water and sanitation to their citizen as basic right for survival but there are reasons which shows that the people still faces some problem related to the water.

The present article interwove right to clean water and sanitation with a base in human rights. It tries to include different existing perspectives regarding the impact of its international recognition as a human right and rights given under Indian Constitution.

Through this paper author tries to discuss about the steps of judiciary related to the water and sanitation issues in India. Finally, author concludes the paper with the urgency and challenge of monitoring the human right to clean water and sanitation
\end{abstract}

Key Words: Clean Water and Sanitation, Constitution, Human Rights, Right to Life, etc.

\section{INTRODUCTION}

It's called "Day Zero": when Cape Town, South Africa's active port city, is in the undesirable situation of being the first major city in the modern era to sees its water taps run dry, and its population thrust into a death-defying situation. The plight of the drought situation in South Africa is just one example of the long been warned about problem of water scarcity by experts. $2 / 3^{\text {rd }}$ part of the Earth is covered by water - still the situation is that out of it only $3 \%$ is fresh and useable for basic necessity of life. Over one billion people lack access to water and another 2.7 billion find it scarce for at least one month of the year. A 2014 survey of the world's 500 largest cities estimates that one in four are in a situation of "water stress". According to UN-endorsed projections, global demand for fresh water will exceed supply by $40 \%$ in 2030, thanks to a combination of climate change, human action and population growth. 892 million people worldwide still practised open defecation. 842,000 people die every year from diseases caused by unsafe water, inadequate sanitation and hygiene.

Harmless and easily available water is important for public health, whether it is used for drinking, domestic use, food production or recreational purposes. Improved water supply and sanitation, along with better administration of water resources, can lift countries' economic growth and can contribute greatly to poverty drop. 


\section{GAP GYAN- An International Peer-Reviewed Open Access Journal of Social Sciences}

In 2010, the UN General Assembly explicitly recognized the human right to water and sanitation. Everyone has the right to sufficient, continuous, safe, acceptable, physically accessible, and affordable water for personal and domestic use.

\section{Intervolving Right to water and sanitation with other Human Rights:}

Water and sanitation being the basic and bare necessity requirement of all human beings, has close connection with basic human rights available to all according to the Universal Declaration of Human Rights adopted by United Nation General Assembly.

The human rights principles below constitute general human rights safeguards that are of particularly important in the realisation of the rights to water and sanitation.

\section{Non-Discrimination and Equality:}

It incorporates both the prohibition of discrimination and the obligation for states to work towards equality in water and sanitation service provision.

\section{Right to Life and Liberty:}

Right to life and liberty cannot be achieved without the basic needs of water and sanitation.

\section{Gender Justice:}

Poverty denies access to basic rights like water and sanitation and women and girls are most affected because they need to walk long distance to fetch water and to defection in open causing women and even new born at the risk of infection.

\section{Right to Health:}

Lack of proper facility of water and sanitation lead to the risk of health - diarrheal diseases, lack of health care facility and even maternity issues of infection to mother and new born child.

\section{Right to Environment:}

Contamination of water due to industrialisation, improper waste management has caused many environmental concerns - which is taking the toll of environment and adding to the environmental disaster. Urbanisation added to the problem of water and increased the deforestation and thus affected environment badly.

\section{Right to Access to Information:}

Access to information refers to the public entitlement to seek and receive information about current and planned water and sanitation law, policies and programmes for example on the provision of services, tariff systems and the quality of water and sanitation which is part of state responsibility

\section{Right of Participation:}

The human rights to water and sanitation can only be realised in an effective manner when people become part of all processes that relate to the realisation of these rights. Any plan or decision-making that relates to the realisation of the rights to water and to sanitation must be developed through a participatory and transparent process.

\section{Right to Sustainability:}

The rights to water and sanitation must be realised for present and future generations. Water and sanitation facilities, services, and water as a resource, must be economically, environmentally and socially sustainable.

\section{International perspective:}

The adoption in 2010 of United Nations (UN) resolutions recognising the Human Right to Safe Drinking Water and Sanitation has opened new perspectives for the achievement of universal access to water and sanitation services. Both the United Nations General Assembly (in July 2010) and the United Nations Human Rights Council (in 


\section{GAP GYAN- An International Peer-Reviewed Open Access Journal of Social Sciences}

September 2010) acknowledged that access to safe drinking water and sanitation is a right implied by the established human right to an adequate standard of living.

UN member states are thus duty bound for the realisation of the rights to clean water and sanitation. Members can be held accountable if the obligation is not fulfilled. There is a close linkage between Human Right to water and sanitation with right to health, development and many more.

In September 2015, at a special session of the UN General Assembly, Heads of State adopted the proposal for a new set of international development goals, the Sustainable Development Goals (SDGs). The SDG framework consists of 17 Goals, with 169 targets - building on the MDGs that governed development planning and implementation between 2000 and 2015. The SDGs go beyond the MDGs in terms of ambition, scope and spirit they embrace universality they address all three pillars of sustainability (the economic, social and environmental aspects); and they are geared towards transformation rather than progress.

A dedicated water and sanitation goal in part of this framework: SDG6, Ensure Availability and Sustainable Management of Water and Sanitation for All. This Goal covers all water and sanitation issues, not only drinking water and sanitation as target 7C of the MDGs did. This comprehensive approach underlines to increasing importance of water scarcity, concerns over water quality and competition for water sources by different sectors. The human right to safe drinking water and sanitation was the only human right specifically referred to in the report of the UN Secretary-General supporting the SDG proposals.

\section{Constitutional Perspective:}

The Constitution of India is the supreme law of India. It is called the "Bible" of Indian citizens. It guarantees various fundamental rights of the citizens for the protection of their life and freedoms, directive principles of state policy to make the state answerable for non-compliance of its duties towards citizens, fundamental duties of the citizens towards state and other human beings for assurance of fundamental rights in a better way. The Indian Constitution has provisions of protection of environment which includes right to water and sanitation facilities. These provisions are the effects of Stockholm conference held at International level regarding various issues of environmental protection (Desai, 1987). There is no express provision pertaining to right to water or sanitation, but judiciary has played its part and gave many judgements in support of right to water and sanitation which has included right to water and sanitation as part of Article 21 - right to life.

\section{Fundamental Rights in Part III of the Constitution:}

Article 14: Equality before law

Article 17: Abolition of untouchability

Article 21: Protection of life and personal liberty: "No person shall be deprived of his life or personal liberty except according to procedure established by law."

There is no express recognition of right to water and sanitation in the constitution book - the fundamental rights nor any mention in the directive principles (Sharma, 2015). The rights Under Article 21 are collection of different types of rights altogether which are derived from the Fundamental Rights of the Constitution. Right to water and sanitation is included in Article 21 by The Supreme Court in India (Norbert Brunner, 2015).

\section{The Directive Principles of State Policy in Part IV of the Constitution:}

The use of the word "Environment" in border sense includes right to water and sanitation. It needs to be underlined that the directive of Article 39, Article 42, Article 47 and 48A requires the state not only to adopt protection but also to improve environment

Article 39: $\quad$ The State shall, in particular, direct its policy towards securing: that the ownership and control of the material resources of the community are so distributed as best to sub serve the common good; 


\section{GAP GYAN- An International Peer-Reviewed Open Access Journal of Social Sciences}

that the operation of the economic system does not result in the concentration of wealth and means of production to the common detriment.

Article 42: $\quad$ Provision for just and humane conditions of work and maternity relief

Article 47: $\quad$ Duty of the State to raise the level of nutrition and the standard of living and to improve public

health:

Article 48A: $\quad$ Protection and improvement of environment and safeguarding of forests and wildlife.

Fundamental Duties of the Citizen of India:

Article 51 (A) (g) specifically deals with the fundamental duty with respect to Environment.

Article 51 (A) (g) It shall be the duty of every citizen of India - to protect and improve the natural environment including forests, lakes, rivers and wild life, and to have compassion for living creatures. Surprisingly Article 51 (A) (g) imposes duty only on "citizens". This can be construed as no obligation on "non-citizens". There is no enforcement mechanism for compliance of these duties - living them like "lion without teeth". It is not comprehensive enough to cover all forms of environmental pollution which are recently increasing like Nosie, light, radioactive and hazardous wastes etc.

A commission has been constituted to review the constitution by the government a decade ago and proposed for the new Article $30 \mathrm{D}$ which recognised that every person shall have right to safe drinking water.

Article 262: Adjudication of disputes relating to waters of inter State Rivers or river valleys. Water rights exist in the Indian Constitution as riparian rights under Article 262 which was created to resolve state river water disputes.

Originally the "Right to safe drinking water" is not a part of the constitution as a fundamental right.

It is interesting to note that there is no specific right to sanitation mention anywhere in the Constitution of India. Only Directive Principle for the State mention the environmental and health concern with are connected to sanitation facility.

\section{Judicial Approach:}

Fundamental right to clean water and sanitation is been evolved out of judicial pronouncement. There are no legislative actions taken to give such right a specific fundamental right guaranteed under the Constitution of India.

\section{Right to Life Includes Right to Clean Water and Right to Sanitation:}

Supreme Court of India included right to water and right to sanitation as implied rights in the broad interpretation of Article 21. Right to life in its broadest sense include right to clean water and right to sanitation facilities - basic need to sustain a decent life. Intrinsic link between life and water and sanitation facilities is implied in any human rights instrument or bill of rights, whether it is explicitly recognized or not.

In the earlier 1980's, the higher judiciary read the right to sanitation within the right to life under Article 21 of the Constitution. And in earlier 1990's, the higher judiciary read the right to water within the right to life under Article 21 of the Constitution This was much before the right to water became a subject to interest at the international level.

Looking the views of courts in the era of seventies and eighties, government of different states realised the need to legislate law which is far more stringent and comprehensive to provide clean water and sanitation to common people. The water (Prevention and Control of Pollution) Act, 1974 and the Environment Protection Act, 1986 were implemented to protect water and environment.

Judicial Pronouncement on Right to Clean Water:

In an important ruling of “A.P. Pollution Control Board II v. Prof. M.V. Nayudu," (2001) the Indian Supreme court held that safe drinking water is the first importance in any country. The court further held that under Article 21 there is a duty on the State to provide clean drinking water to its citizens. 


\section{GAP GYAN- An International Peer-Reviewed \\ Open Access Journal of Social Sciences}

In "Narmada Bachao Andolan Vs. Union of India" (2000) the Supreme Court uphold the Indian government's decision to construct over 3,000 dams on the river Narmada but considered the importance of Right to safe drinking water as well and held that "water is the basic need for the survival of the human beings and is part of right of life and human rights as enshrined in Article 21 of the Constitution of India.

In the case of M.C. Mehta vs. Kamal Nath (1997) Court held that our legal system based on English common law and includes public trust doctrine as a part of jurisprudence. The state is the trustee of all-natural resources which are by nature meant for public use and enjoyment. The state as a trustee under legal duty to protect all the resources - water being part of the same.

In the Vallore Citizen Welfare Forum vs. Union of India (1997) Supreme Court expressly held that the constitutional and statutory provisions protect a person's right to fresh air, clean water and pollution free environment.

In the case of BandhuaMuktiMorcha vs. Union of India (1984) held that the entitlement of citizens to receive safe drinking water (potable water) is part of the right to life under Article 21.

In the case of Subhas Kumar vs. State of Bihar (1991), the Supreme Court asserted that the right to live is fundamental rights given under Article 21 of Indian Constitution and it includes right to clean water and pollution free air for enjoyment of life.

In important judgment of Voice of India vs. Union of India (2010), Supreme Court accepted the fact that after 60 years of independence Indian legislature not able to provide clean water to the Indian citizen and it needs to a special executive attention.

Many judgements are given by High Courts of India to show importance of right to water.

In the case of Hamid Khan V State of Madhya Pradesh High Court of MP found that under Article 47, the state has a duty 'towards every citizen of India to provide pure drinking Water'. The judgement makes it clear that it the duty of the State to take care of the basic needs of the citizens.

In Vishala Kochi Kudivella Samarkshana Samithi V State of Kerala, the High Court of Kerala held that "We have no hesitation to hold that failure of the State to provide safe drinking water to the citizens in adequate quantities would amount to a violation of the fundamental right to life."

\section{Judicial Pronouncement on Right to Sanitation:}

In several judgement decided by Supreme Court and High Court, right to sanitation is evolved as a Right included in Article 21 - Right to Life.

In the landmark judgement, Municipal Council, Ratlam V Vardhichand and Others, laid the ground for all subsequent decisions, upheld the order of the High Court and directed the Municipality to take immediate action within its statutory powers to construct sufficient number of public latrines, provide water supply and scavenging services, to construct drains, cesspools and to provide basic amenities to the public.

In Virendra Gaur and Others V. State of Haryana and Others, The Court held that it is constitutional obligation on State Government and Municipalities to ensure and safeguard proper environment and to take adequate measures to promote, protect and improve both man-made and natural environment. The lands have vested in Municipality and Government has no right and title or interest there. The Court further held that grant of lease by Government was without authority of law and jurisdiction.

In LK Koolwal V. State of Rajasthan and others, 1986 the court held that it is primary, mandatory and obligatory duty of the Municipal Council to remove filth, rubbish, night soil, odour or any other noxious or offensive matter. There cannot be any plea whether the funds are available or not. A good number of affidavits have been filed by the citizens of Jaipur to support the writ petition to show that sanitation problem is acute in Jaipur which is hazardous to the life of the citizens of Jaipur. Insanitation lead to slow poisoning and adversely affect the life which lead to death at an earlier date than the natural death.

In Dr K C Malhotra V State of Madhya Pradesh and Others, 1993 Supreme Court looking to the facts held that inhabitants of the locality may be of backward class or weaker sections of the society or community at large have got a fundamental right under Article 21 of the Constitution entitling them to live as human beings which is in the limit of Municipal Corporation. Court ordered that there must be a separate sewage line from which the filthy water may flow out. The nalla must be covered and there should be proper lavatories for public conservancy 


\section{GAP GYAN- An International Peer-Reviewed Open Access Journal of Social Sciences}

which should be regularly cleaned. Public health and safety cannot suffer on any count and Article 47 make it mandatory for Government to take steps for the improvement of public health as among primary duties.

In Safai Karamchari Andolan and Others V. Union of India and Others, 2014 The above writ petition has been filed by the petitioners as a Public Interest Litigation under Article 32 of the Constitution of India praying for issuance of a writ of mandamus to the respondent-Union of India, State Governments and Union Territories to strictly enforce the implementation of the Employment of Manual Scavengers and Construction of Dry Latrines (Prohibition) Act, 1993 (in short 'the Act'), inter alia, seeking for enforcement of fundamental rights guaranteed under Articles 14, 17, 21 and 47 of the Constitution of India.

\section{CONCLUSION}

"All human beings are born free and equal in dignity and rights" as has been stated under Article 1 of the Universal Declaration of Human Rights, 1948. The Article is enough to explain the importance of Human Rights to an individual on the earth. Right to live with dignity and equality cannot be achieved without the basic necessity is made available to all human race. Basic necessity includes, food, shelter, clothing, water and sanitation facilities. The adoption in 2010 of United Nations (UN) resolutions recognising the Human Right to Safe Drinking Water and Sanitation has opened new perspectives for the achievement of universal access to water and sanitation services. The United Nations General Assembly (in July 2010) and the United Nations Human Rights Council (in September 2010) acknowledged that access to safe drinking water and sanitation is a right implied by the established human right to an adequate standard of living. Close connection between environment, health and availability of clean water and sanitation has made it mandatory for the member country to give greater importance to the topic which was largely ignored. They can therefore be held accountable for progress towards their full realisation.

There is no doubt about the importance of clean water and sanitation as it has direct connection to the economic development and more importantly sustainable development of any country.

Above amplification makes it clear that Indian Constitution has not been efficacious in recognizing the human right to safe drinking water and sanitation.

Water supply and sanitation is a State responsibility under the Indian Constitution. States may give the responsibility to the Panchayat Raj Institutions (PRI) in rural areas or municipalities in urban areas, called Urban Local Bodies (ULB). Except for the National Capital Territory of Delhi and other Union Territories, the central Ministries only have an advisory capacity and a limited role in funding. Sector policy thus is a prerogative of state governments.

Citizen understand the language of "rights" in modern society. So current times, legalistic societies of today "formal law' has become more important.

Water law was essentially concerned with land rights and with irrigation. Gradually understanding the importance of water pollution, Water (Prevention and Control of Pollution) Act, 1974 was enacted. There is no explicit law which gives importance to clean water as basic human right also for conservation and protection. Cities like Bangalore and Shimla are facing acute shortage of water and it is been estimated that 1 out of 4 cities will continue to face water problems if the problem is not taken into consideration by the legislator as top priority.

Sanitation law is characterized by the absence of any legislation that deals with all the dimensions of sanitation. There is scattered law in different Acts which may include sanitation related provisions. Recently, The Prohibition of Employment as Manual Scavengers and their Rehabilitation Act, 2013 is enact for the rights of Manual scavengers after the judicial activism shown by the Supreme Court of India.

There is conceptual gap and no express provisions has been explored so far as a legislative measure in India for the problems faced by human beings relating to Water and Sanitation issues. This gap has been bridged by the judiciary with liberal interpretation of various provisions of Constitution of India.

Youth of the country understand the language of legalism, and thus a comprehensive Law for Water and Sanitation will help the citizen reach the goal of Right to Clean Water and Sanitation as a Basic Human Rights and make our 


\section{GAP GYAN- An International Peer-Reviewed Open Access Journal of Social Sciences}

country increase the standard of living. Dichotomy can be seen from the facts that judiciary is active in giving judgements in favour of right to water and sanitation and making these rights as fundamental rights under Article 21 by broad interpretation but on the counterpart, legislation is not taking active part to make it a law which simplify the work of policy making by the government.

\section{REFERENCES}

$>$ Cape Town is running out of water, and no one knows what economic impact that will have. Published Tue, Mar 62018 CNBC News. https://www.cnbc.com/2018/03/06/south-africa-cape-town-droughteconomic-impact.html

$>$ United Nations, UNWater. https://www.unwater.org/water-facts/scarcity/

$>$ United Nations, UNWater. https://www.unwater.org/water-facts/scarcity/

$>$ WHO-UNICEF. https://washdata.org/reports

$>$ UN WHO. https://www.who.int/en/news-room/fact-sheets/detail/drinking-water

$>$ United Nations, Universal Declaration of Human Rights. http://www.un.org/en/universal-declarationhuman-rights/

$>$ UN CESCR 'General Comment 15' (n 1) [11].

$>$ UNHRC Independent Expert on the Issue of Human Rights Obligations Related to Access to Safe Drinking Water and Sanitation, 'Good Practices' related to Access to Safe Drinking Water and Sanitation: Questionnaire' (2010) [question no 10].

$>$ On 28 July 2010 the United Nations General Assembly, at its 64th session, adopted Resolution A/64/292 (The Human Right to Water and Sanitation) http://www.un.org/es/comun/docs/?symbol = A/RES/64/292\&lang = E ; on 28 September the UN Human Rights Council, at its 18th session, adopted Resolution A/HRC/RES/18/1 (The Human Right to Safe Drinking Water and Sanitation) http://www.un.org/es/comun/docs/?symbol = A/HRC/RES/18/1\&lang = E.

$>\mathrm{UN}$ (2014). The road to dignity by 2030: ending poverty, transforming all lives and protecting the planet. https://sustainabledevelopment.un.org/majorgroups/post2015/synthesisreport

$>$ Praveen, P. (2014). Article 21: a Reservoir of Right to Water. Bhatter College Journal of Multidisciplinary Studies, IV.

$>$ The Constitution of India. https://www.india.gov.in/sites/upload files/npi/files/coi_part full.pdf

$>$ Sharma, B. K. (2015). Constitution of India. New Delhi: Prentice hall India learning Private Ltd.

$>$ Norbert Brunner, V. M. (2015). The Human Right to Water in Law and Implementation. Laws, 413-437.

$>$ It needs to be noted here that, the Sardarswaran Singh Committee recommended that Parliament be empowered to enact legislation imposing penalties or punishment to enforce Article 51 (A) (g). This recommendation was, however, deleted from the final amendment.

$>$ India, G. o. (2002). National Commission to review the working of the Constitution. New Delhi: Government of India.

$>$ Mary, R. (2006). Right to Water: Theoretical concern and practical issues. The Indian Journal of Political Science, 759-766.

$>$ Committee on Economic, Social and Cultural Rights, General Comment 15: The Right to Water, UN Doc. E/C. 12/2002/11 (2002).

$>$ water (Prevention and Control of Pollution) Act,1974. http://legislative.gov.in/actsofparliamentfromtheyear/water-prevention-and-control-pollution-act1974

$>$ Environment Protection Act, 1986. http://legislative.gov.in/actsofparliamentfromtheyear/environmentprotection-act-1986

$>$ A.P. Pollution Control Board II v. Prof. M.V. Nayudu 2 SCC 62 (Supreme Court 2001).

$>$ Narmada Bachao Andolan Vs. Union of India, 10 SCC 664 (Supreme Court 2000).

$>$ M.C. Mehta vs. Kamal Nath 1 SCC 388 (Supreme Court 1997).

$>$ Vallore Citizen Welfare Forum vs. Union of India 5, SCC 647 (Supreme Court 1997). 


\section{GAP GYAN- An International Peer-Reviewed Open Access Journal of Social Sciences}

Dandhua Mukti Morcha Vs. Union Of India, AIR SC 804 (Supreme Court 1984).

$>$ Subhas Kumar Vs. State of Bihar, 1 SCC 598 (Supreme Court 1991).

$>$ Voice of India Vs. Union of India, 8415/2009 (Supreme Court 2010).

$>$ Hamid Khan v. State of Madhya Pradesh, AIR 1997 MP 191 (Madhya Pradesh High Court, 1996), para 6.

$>$ Vishala Kochi Kudivella Samarkshana Samithi V State of Kerala, 2006 (1) KLT 919 (High Court of Kerala, 2006), para 3.

$>$ Municipal Council, Ratlam V Vardhichand and Others AIR 1980 SC 1622 (Supreme Court of India, 1980)

$>$ Virendra Gaur and Others V. State of Haryana and Others

$>\quad$ LK Koolwal V. State of Rajasthan and others, 1986.AIR 1988 Raj 2 (High Court of Rajasthan,1986)

$>$ Dr K C Malhotra V State of Madhya Pradesh and Others, 1993AIR 1994 MP 48 (High Court of Madhya Pradesh, 1993)

$>$ Safai Karamchari Andolan and Others V. Union of India and Others, 2014. (4) SCALE 165 (Supreme Court of India, 2014)

> UN, Universal Declaration of Human Rights. https://www.un.org/en/universal-declaration-humanrights/

1. Ramaswamy R. Iyer, Former Secretary, Ministry of Water Resources, India.

2. United Nations - Sustainable Development Goals

3. https://www.un.org/sustainabledevelopment/water-and-sanitation/

4. P.H. Gleick, "The Human Right to Water" (1999) 1 (5) Water Policy

5. Cullet, P. 2009. Water Law, Poverty, and Development: Water Law Reforms in India. Oxford University Press.

6. Baer, M. and A. Gerlak. 2010. "Implementing the Human Right to Water and Sanitation: A study of Global and Local Discourses", Third World Quarterly, 36(8): 1527.

7. Khurana, Indira and R. Sen. 2009. “Towards Understanding the Right to Water and Sanitation." New Delhi: WaterAid India.

8. A.P. Pollution Control Board II v Prof. M.V. Naidu and Others (Civil Appeal Nos. 368-373 of 1999). Cited from John Lee 'Right to Healthy Environment', Columbia Journal of Environmental Law, Vol. 25, 2000.

9. Subhash Kumar vs State Of Bihar And Ors on 9 January, 1991, 1991 AIR 420, 1991 SCR (1)5.

10. M. C. Mehta vs Kamal Nath \& Ors on 15 March, 2002, (1997)1 SCC 388.

11. Narmada Bachao Andolan v. Union of India and Others, Writ Petition (C) No. 319 of 1994.

12. P.R. Subas Chandran vs Govt. Of A.P. And Others on 24 August, 2001, 2001 (5) ALD 771, 2001 (6) ALT 133.

13. A.P. Pollution Control Board Ii vs Prof.M.V. Nayudu (Retd.)And Ors on 1 December, 2000,(2001) 2 SCC 62.

14. C. Ramachandraiah, "Right to Drinking Water in India”, ILR, 2001: 85-104.

15. P. Pollution Control Board v. Prof. M. V. Nayudu, JT2000 (Suppl3) SC322.

16. A comprehensive scheme of administrative regulation through the permit system of the Water. 